\title{
PENDIDIKAN SEJARAH TERHADAP PENDIDKAN KARAKTER
}

\author{
Dana Rizki Firdaus \\ 1810111110004 \\ Email : danarizki4@gmail.com \\ Program Studi Pendidikan Sejarah Fakultas Keguruan dan Ilmu Pendidikan \\ Universitas Lambung Mangkurat \\ Banjarmasin
}

\begin{abstract}
Abstrak
Pendidikan adalah upaya untuk membentuk karakter siswa sehingga mereka dapat mengetahui dan membedakan antara yang baik dan buruk dalam kehidupan bermasyarakat, berbangsa dan bernegara. Pendidikan karakter saat ini sangat diperlukan untuk mengatasi masalah generasi penerus bangsa ini yang semakin sulit dikendalikan. Tanpa pendidikan sama sekali mustahil suatu kelompok manusia dapat hidup berkembang dengan cita-cita untuk maju, sejahtera, dan bahagia menurut konsep pandangan hidupnya. Begitupula pendidikan sejarah memiliki aspek strategis sebagai salah satu media pendidikan dalam membangun karakter bangsa. Pemahaman sejarah perlu dimiliki setiap orang sejak dini agar mengetahui dan memahami makna dari peristiwa masa lampau sehingga dapat digunakan sebagai landasan sikap dalam menghadapi kenyataan pada masa sekarang serta menentukan masa yang akan datang.
\end{abstract}

\section{PENDAHULUAN}

Pendidikan adalah kegiatan sosial budaya masyarakat dan bangsa yang sangat penting dalam membangun dan mengembangkan kualitas warganegara dan bangsa untuk kehidupan masa kini dan yang akan dating dan sebagai seorang pendidik memiliki tanggung jawab besar dalam mencerdaskan kehidupan bangsa, tentu hal ini bukan menjadi hal yang mudah.seorang pendidik juga bertanggung jawab dalam hal membangun karakter peserta didik. Melalui Pendidikan sejarah bisa menjadi jalan seorang pendidik untuk membangun karakter peserta didik. Sebagaimana Peraturan Menteri Pendidikan Nasional (Permendiknas) Nomor 22 Tahun 2006 menegaskan bahwa pengetahuan masa lampau mengandung nilai-nilai kearifan 
yang dapat digunakan untuk melatih kecerdasan, membentuk sikap, watak dan kepribadian peserta didik. Untuk itu nilai-nilai sejarah harus dapat tercermin dalam pola prilaku nyata peserta didik. Tujuan pembelajaran sejarah menurut (Anis, 2016: 487) adalah untuk mengembangkan berpikir kreatif, dan kritis, mengembangkan rasa ingin tahu, inspirasi dan aspirasi, mengembangkan kemampuan mencari, mengolah, mengemas dan mengkomunikasikan informasi, dan yang penting meningkatkan semangat kebangsaan.

Guru sejarah mempunyai peran yang penting karena guru sejarah akan menjadi yang terdepan dalam proses pembelajaran sejarah di sekolah. Karenanya lah guru sejarah harus mempunyai wawasan yang luas serta mendalam dan mempunyai motivasi yang tinggi dalam proses pembelajaran sejarah sehingga makna yang terkandung dalam mata pelajaran sejarah dapat tersampaikan (Sirnayatin, 2017:313). Guru sejarah mempunyai peran yang penting dalam pengembangan karakter siswa. Selain itu, guru sejarah harus membantu dalam proses menjelaskan nilai-nilai positif di dalam diri siswa yang tidak bisa digantikan oleh media pendidikan secanggih apapun. Guru Sejarah juga menekankan tujuan Pembelajaran sejarah agar tercapai, tujuan sejarah menurut (Anis, 2015:59) adalah untuk mengembangkan pemahaman diri sendiri, sehingga bangsa kita menjadi tahu arti menjadi bangsa indonesia itu, tanpa sejarah generasi muda tidak akan tahu bagaimana para pendahulu sangat gigih dalam memperjuangkan kemerdekaan, tanpa sejarah para politikus generasi baru pun tidak akan pernah tahu struktur negara yang pancasilais yang menjadi ideologi negara.

Pendidikan karakter berkaitan dengan contoh perilaku yang bisa ditiru atau sebagai contoh untuk membangun karakter siswa. Pendidikan karakter pada pembelajaran sejarah memerlukan guru yang dapat menyampaikan makna atau nilai-nilai yang terkadung di dalamnya. Karena tanpa guru, dalam hal ini guru sejarah perlu menggali kembali nilai-nilai yang ada pada pembelajaran sejarah sebagai pijakan untuk menumbuhkan dan mengembangkan karakter bangsa yang sudah pudar. Sebagaimana tujuan Pendidikan Sejarah diantaranya adalah nation and chacarter building. Karakter yang berarti watak atau jati diri (Anis, 2014 : 484) jadi dengan belajar sejarah maka sama dengan belajar tentang jati diri bangsa dan mengenal karakter.

Mempelajari sejarah juga mempunyai kontribusi yang sangat besar karena dengan mempelajari sejarah dapat mengembangkan kesadaran sejarah, sehingga nilai-nilai yang ada 
di dalam sebuah peristiwa sejarah dapat diterapkan dalam kehidupan sehari-hari dan mendapatkan pemahaman akan pentingnya masa lalu demi masa depan. Kesadaran sejarah juga merupakan bagian dari pendidikan karakter. Hal ini, adanya kesadaran sejarah, siswa sudah dapat mengaplikasikan dalam kehidupan sehari-hari nilai-nilai atau karakter yang ada pada materi sejarah. Misalnya, siswa dapat mengaplikasikan bentuk cinta tanah air, rasa tanggung jawab dan semangat kebangsaan dalam kehidupan sehari-hari.

\section{PEMBAHASAN}

Karakter diartikan sebagai watak, tabiat, akhlak, atau kepribadian seseorang yang terbentuk dari hasil internalisasi berbagai kebajikan (virtues) yang diyakininya dan digunakannya sebagai landasan untuk cara pandang, berpikir, bersikap, dan bertindak (Hasan, 2012 : 84). Interaksi seseorang dengan orang lain juga menumbuhkan dan mengembangkan karakter masyarakat dan karakter bangsa. Pendidikan Karakter disekolah dengan Menggunakan Pembelajaran sejarah sebagai salah satu cara untuk mendidik karakter peserta didik menjadi hal yang tepat, karena dengan Pendidikan sejarah peserta didik mendapatkan banyak sekali contoh-contoh dalam karakter yang bisa menjadi role model dalam kehidupan. Terdapat banyak tokoh yang bisa diajarkan dalam Pendidikan sejarah, kita ambil contoh presiden pertama Republik Indonesia Soekarno, sabagiaman perjuangan beliau dalam memperjuangkan hak hak kemedrekaan Republik Indonesia. Siapa yang tidak tahu perjuangan berat Soekarno dalam memperjuangkan kemedrekaan Indonesia, semua tahu tapi yang menjadi persoalan ialah Semangat perjuangan Soekarno tidak di implementasikan dalam kehidupan nyata sebagai rola model. Hal ini yang hilang pada masa sekarang, semangat perjuangan yang dimiliki para tokoh kita tidak dimiliki para penerus bangsa pada saat ini. Hal ini lah menjadi tugas seorang guru dalam Pendidikan sejarah bagaimana mengajarkan kepada siswa tidak hanya tentang materi sejarah namun juga mengajarkan semangat juang yag luar biasa sehingga siswa bisa sadar dan mengambil contoh serta di implementasikan pada kehidupan nyata. 
Mata pelajaran Sejarah memiliki peran dalam pembentukan watak dan peradaban bangsa yang bermartabat serta dalam pembentukan manusia Indonesia yang memiliki rasa kebangsaan dan cinta tanah air. Meski pun pelajaran sejarah merupakan salah satu bagian dari pendidikan karakter, materi pendidikan sejarah yang khas dan penuh dengan nilai memiliki paling memiliki potensi kuat untuk memperkenalkan kepada peserta didik tentang bangsa dan aspirasinya di masa lampau. Melalui pelajaran sejarah peserta didik dapat melakukan kajian mengenai apa dan bila, mengapa, bagaimana, serta akibat apa yang timbul dari jawaban masyarakat bangsa di masa lampau tersebut terhadap tantangan yang mereka hadapi serta dampaknya bagi kehidupan peristiwa itu dan masa kini ( Hasan, 2012:88)

Materi pendidikan sejarah akan mampu membangun memori kolektif sebagai bangsa hasil belajar apabila ada proses identifikasi yang kuat dari peserta didik terhadap peristiwa sejarah yang dipelajari. Untuk itu ada beberapa kriteria dalam memilih materi pendidikan sejarah. Tujuan pendidikan sejarah di jenjang pendidikan dasar memberikan rambu-rambu mengenai pemilihan peristiwa sejarah untuk menjadi pokok bahasan. Dengan rambu-rambu ini maka peritiwa sejarah terpilih harus memberikan keadaran kepada diri peserta didik tentang bangsa ini, nilai-nilai yang diperjuangkan bangsa, semangat persatuan yang mengalami berbagai tantangan dan hambatan tetapi selalu dapat diselesaikan dengan baik. Pemilihan peristiwa itu harus dimulai dari peristiwa yang paling dekat dengan lingkungan peserta didik, meluas hingga ke peristiwa yang bersifat nasional. Dalam pembelajaran sejarah guru seharusnya juga dapat mengaitkan materi materi sejarah dengan kehidupan nyata peserta didik di lingkungan mereka masing-masing, agar materi yang di ajarkan guru itu dirasa bermanfaat bagi peserta didik itu sendiri. Apabila dalam dunia pendidikan, para siswa diarahkan oleh guru untuk mengembangkan pemikiran seperti tujuan sejarah itu, maka siswa pastinya akan menjadi kritis dalam setiap peristiwa peristiwa sejarah nasional Indonesia maupun sejarah lainnya, dan akan timbul rasa ingin tahu yang besar, dari rasa ingin tahu itu siswa akan semakin kreatif untuk menggali informasi yang mendalam dari berbagai sumber untuk mencari kebenaran dari peristiwa yang diamatinya. Dan dari situlah siswa akan menyadari bahwa ilmu sejarah itu penting untuk dipelajari. Menumbuhkan karakter peserta didik agar sesuai dengan tujuan pendidikan nasional tentu tidak semudah yang di bayngkan, harus di barengi dengan kebiasaan kebiasaan positif yang dilakukan secara 
berkesinambungan dalam lingkungan kelas seperti membuka pembelajaran dengan di sisipkan lagu lagu kebangsaan, kemudian memperkenalkan tokoh tokoh bangsa indonesia yang turut serta berjuang untuk bangsa ini, mempelajari biografi pahlawan, serta mengarahkan peserta didik akan pentingnya menghargai waktu, selanjutnya mengimpelemtasikan dalam kebiasaan sehari hari dengan tidak terlambat kesekolah, ini adalah sebagian upaya yang dapat dilakukan secara berkesinambungan untuk melakukan kebiasaan yang positif dalam lingkungan nyata.

Materi pelajaran sejarah memberikan informasi bukan hanya kesuksesan pelaku sejarah pada masa lalu namun kegagalan yang pernah dialamipun tidak luput dari sorotan sejarah, maka hal itu tentu akan memberikan pengajaran kepada masa kini tentang bagaimana harus bersikap dan cara apa yang harus dilakukan apabila peristiwa yang serupa di alami, merujuk dari pelaku dan peristiwa sejarah terdahulu. Pembelajaran sejarah memiliki posisi yang sangat penting di dunia pendidikan karena nilai-nilai yang terkandung merupakan aspek terpenting dalam pembangunan identitas bangsa. Pembelajaran sejarah lebih membimbing siswa untuk dapat memotivasi dan memaknai setiap peristiwa yang terjadi pada masa lampau sebagai pembelajaran hidup. (Alfiah,2017:4)

\section{SIMPULAN}

Pendidikan sejarah sebagai pendidikan yang mempelajari peristiwa masa lalu merupakan sarana nilai karakter dari generasi sebelumnya ke generasi berikutnya, menumbuhkan karakter melalui pendidikan sejarah bukanlah sekedar menghafal dan mengetahui peristiwa tersebut, melainkan mengembangkan dan mengimplementasikan dalam kehidupan sehari hari. Mampu merubah cerita sejarah yang tidak terkait dengan masa kini, menjadi pengajaran yang yang kaya akan nilai nilai yang dapat di terapkan dalam kehidupan saat ini. Penanaman dan penerapan nilai-nilai kepahlawanan para pejuang bangsa indonesia sangat penting dan diperlukan dalam membentuk keperibadian generasi bangsa yang berkarakter dan bermoral serta memiliki semangat kebangsaan, dan cinta tanah air, merasa bangga menjadi bagian dari bangsa indonesia. 


\section{REFERENSI}

Anis, M. Z. A. (2015). Sejarah Bukan Warisan Melainkan Pembelajaran.

Anis, M. Z. A. (2016). Sejarah, Kesadaran Sejarah dan Pupusnya Identitas Nasional.

Sirnayatin, T. A. (2017). Membangun Karakter Bangsa Melalui Pembelajaran Sejarah. SAP (Susunan Artikel Pendidikan), 1(3).

Hasan, S. H. (2012). Pendidikan sejarah untuk memperkuat pendidikan karakter. Paramita: Historical Studies Journal, 22(1).

Alfiyah, R. (2017). Peran Guru Sejarah dalam Pengembangan Karakter Siswa Melalui Pembelajaran Sejarah Lokal di SMA Negeri 1 Ambarawa (Doctoral dissertation, Universitas Negeri Semarang). 